\title{
INTERVENSI SUPLEMEN MAKANAN UNTUK MENINGKATKAN KADAR HEMOGLOBIN PADA IBU HAMIL
}

\author{
Eti Rimawati, ${ }^{1}$ Erna Kusumawati, ${ }^{2}$ Elviera Gamelia, ${ }^{2}$ Sumarah, ${ }^{3}$ Sri Achadi Nugraheni ${ }^{4}$ \\ ${ }^{1}$ Fakultas Kesehatan, Universitas Dian Nuswantoro, Semarang \\ ${ }^{2}$ Fakultas Ilmu Ilmu Kesehatan, Universitas Soedirman, Purwokerto \\ ${ }^{3}$ Program Studi Kebidanan, Poltekkes Kementerian Kesehatan, Yogyakarta \\ ${ }^{4}$ Fakultas Kesehatan Masyarakat, Universitas Diponegoro, Semarang
}

\section{FOOD SUPPLEMENT INTERVENTIONS FOR INCREASING HEMOGLOBIN LEVEL ON PREGNANT WOMEN}

\begin{abstract}
Background: Anemia in pregnancy has become a major global health problem nowadays because it affects nearly half of the pregnant women population worldwide. Anemia in pregnant women is caused by iron deficiency, deficiency of folic acid, infection and blood abnormalities. The effort used to reduce the anemia rate of pregnant women is by giving iron supplements as much as 90 tablets as well as fullfilment of nutritional intake during pregnancy. The purpose of this literature review is to illustrate the effects of supplementation on elevated HB levels in pregnant women.

Method: The method used to search the necessary data is sourced from Google Scholar which there are 11 articles dated from 2010-2018. The data analysis used is descriptive in matrix form.

Result: The result of this literature review is that the provision of Fe supplements, the consumption of ironcontaining foods such as sweet potatoes, and the consumption of enhancer Fe absorbents such as Tinutuan, fruits containing vitamin $C$ such as guava juice, red spinach, and foods high in vitamins B9 and B12 such as green beans and seaweed can increase blood hemoglobin levels in pregnant women. In addition, limiting foods containing substances that can inhibit the absorption (inhibitor) Fe also has an effect to optimize absorption of Fe in the body.

Conclusion: Pregnant women need to increase the consumption of foods containing vitamin C, B12, folic acid and proteins to increase the absorption of Fe and avoid consuming food that can inhibit the absorption of Fe such as tea, coffee and milk.
\end{abstract}

Keywords: Pregnant women, anemia, hemoglobin level

\begin{abstract}
ABSTRAK
Latar belakang: Anemia pada kehamilan saat ini menjadi masalah kesehatan global utama karena telah mempengaruhi hampir setengah dari semua wanita hamil di seluruh dunia. Anemia pada ibu hamil disebabkan oleh kekurangan zat besi, kekurangan asam folat, infeksi dan kelainan darah. Upaya untuk menurunkan angka anemia ibu hamil yaitu dengan pemberian supplement zat besi sebanyak 90 tablet serta pemenuhan asupan gizi pada saat hamil. Tujuan dari literatur review ini adalah untuk menggambarkan pengaruh suplementasi makanan terhadap peningkatan kadar $\mathrm{Hb}$ pada ibu hamil.

Metode: Metode pencarian data bersumber dari google scholar yang berjumlah 11 artikel dari tahun 2010 2018. Analisis data dilakukan secara deskriptif dalam bentuk matriks.

Hasil Penelitian: Hasil literature review ini adalah bahwa pemberian supplement Fe, konsumsi makanan yang mengandung zat besi seperti ubi jalar, dan konsumsi makanan yang mengandung zat pembantu penyerapan $\mathrm{Fe}$ (enhancer $\mathrm{Fe}$ ) seperti tinutuan, buah-buahan yang mengandung vitamin $\mathrm{C}$ seperti jus jambu, bayam merah dan buah bit, serta makanan tinggi vitamin B9 dan B12 seperti kacang hijau dan rumput laut dapat meningkatkan kadar Hemoglobin darah pada ibu hamil. Selain itu pembatasan makanan yang mengandung zat yang dapat menghambat penyerapan (inhibitor) Fe juga berpengaruh untuk mengoptimalkan absorbsi Fe dalam tubuh.

Kesimpulan: Ibu hamil perlu meningkatkan konsumsi makanan yang mengandung vitamin C, B12, asam folat dan protein untuk meningkatkan absorbsi Fe dalam tubuh serta menghindari mengkonsumsi makanan sumber Fe bersamaan dengan makanan yang dapat menghambat absorbsi Fe seperti teh, kopi dan susu.
\end{abstract} Kata Kunci: Ibu hamil, anemia, kadar hemoglobin

Alamat Koresponding: Eti Rimawati, Fakultas Kesehatan, Universitas Dian Nuswantoro, Semarang, email:eti.rimawati@dsn.dinus.ac.id 


\section{PENDAHULUAN}

Angka Kematian Ibu (AKI) di Indonesia tahun 2013 sebesar 359/100.000, masih di bawah target MGD's yaitu 102/100.000 kelahiran hidup. Penyebab terbesar dari kematian ibu yaitu perdarahan $(30,3 \%)$, hipertensi $(27,1 \%)$, infeksi $(7,3 \%)$, partus lama $(1,8 \%)$, lain-lain $(40,8 \%)$ karena penyakit kanker, ginjal, jantung dan penyakit lain. ${ }^{1}$ Perdarahan merupakan salah satu penyebab kematian ibu dapat terjadi pada masa kehamilan, persalinan maupun masa nifas.

Anemia pada ibu hamil menjadi masalah kesehatan global karena telah mempengaruhi setengah dari semua wanita hamil di seluruh dunia. ${ }^{2}$ Diperkirakan terdapat $41,8 \%$ ibu hamil di dunia mengalami anemia dan hampir sebagian besar dikarenakan zat besi dengan kadar $\mathrm{Hb}$ kurang dari $11 \mathrm{mg} / \mathrm{L} .^{3}$ Kebutuhan zat besi pada bu hamil adalah $1.190 \mathrm{mg}$ zat besi untuk mempertahankan kehamilan dan proses persalinan. ${ }^{4}$ Cakupan pemberian tablet $\mathrm{Fe}$ pada ibu hamil menunjukkan 32,5\% masih jauh dari target tahun 2014, 95\%. ${ }^{3}$ Data Riskesdas 2013 menunjukkan prevalensi anemia pada WUS (Wanita Usia Subur) usia $>15$ tahun sebesar $22,7 \%$, sedangkan pada ibu hamil sebesar $37,1 \% .^{5}$

Kekurangan zat besi, kekurangan asam folat, infeksi dan kelainan darah menyebabkan anemia pada ibu hamil. Anemia pada ibu hamil berdampak saat kehamilan, persalinan maupun masa nifas. Dampak anemia pada ibu hamil yaitu 1) Gangguan pertumbuhan, pada sel tubuh maupun sel otak, 2) mengakibatkan kurangnya oksigen yang ditransfer ke sel tubuh maupun ke otak. Anemia pada ibu dapat mengalami perdarahan postpartum yang disebabkan karena atonia uteri. ${ }^{4}$

Upaya untuk menurunkan angka anemia ibu hamil yaitu dengan pemberian supplement zat besi sebanyak 90 tablet selama
Trimester ke III serta pemenuhan asupan gizi yang sesuai ketika hamil sehingga kebutuhan zat besi terpenuhi, untuk meningkatkan jumlah sel darah merah dan membentuk sel darah merah janin dan plasenta. ${ }^{6}$ Beberapa penelitian telah dilakukan dalam suplementasi $\mathrm{Fe}$ pada ibu hamil, sehingga penelitian ini bertujuan untuk menggambarkan pengaruh suplementasi terhadap peningkatan kadar $\mathrm{Hb}$ ibu hamil.

\section{METODE}

Penelitian ini merupakan suatu tinjauan literature (literature review) dengan metode naratif yang mencoba menggali hasil penelitian di Indonesia yang terkait dengan suplementasi untuk meningkatkan kadar $\mathrm{Hb}$ pada ibu hamil. Sumber pencarian data melalui pencarian sistematis database terkomputerisasi dari google cendekia (google scholar) dari tahun 2010 - 2018 tentang anemia ibu hamil, berjumlah 11 jurnal penelitian. Hasil penelitian dipilih berdasarkan hasil penelitian yang sudah dipublikasikan di jurnal, dimana kriteria inklusi hanya jurnal yang ada di Indonesia dengan pertimbangan tingginya kasus anemia ibu hamil di Indonesia dan kesamaan budaya kebiasaan masyarakat. Kajian ini tidak termasuk hasil penelitian yang belum dipublikasikan dan prosiding.

\section{HASIL PENELITIAN}

Literatur Review ini menjelaskan tentang berbagai intervensi suplemen makanan yang dapat meningkatkan kadar hemoglobin darah pada ibu hamil seperti pemberian suplemen $\mathrm{Fe}$, makanan sumber enhancer $\mathrm{Fe}$ serta pembatasan makanan yang mengandung inhibitor Fe. Berdasarkan hasil kajian terhadap 11 jurnal penelitian, maka dapat ditampilkan dalam tabel ringkasan hasil penelitan sebagai berikut: 
Tabel 1.

Hasil Penelitian dari Tinjauan Literatur

\begin{tabular}{|c|c|c|c|c|c|c|}
\hline No & Penulis & Desain & $\begin{array}{l}\text { Jenis } \\
\text { Suplemen } \\
\text { Makanan }\end{array}$ & Sampel & Metode, Lama Intervensi & Hasil \\
\hline 1 & $\begin{array}{l}\text { Fredrika N. Losu, } \\
\text { Sjenny Tuju, } \\
\text { Fonnie Kulu }{ }^{7}\end{array}$ & $\begin{array}{l}\text { - Eksperimental } \\
\text { - teknik one group } \\
\text { pretest and post test } \\
\text { design }\end{array}$ & $\begin{array}{l}\text { Makanan } \\
\text { tradisional } \\
\text { Manado: } \\
\text { Tinutuan }\end{array}$ & 25 ibu hamil & $\begin{array}{l}\text { Pemberian tablet Fe } 90 \text { tablet dengan } \\
\text { membatasi konsumsi teh dan kopi, } \\
\text { ditambakan menu tradisional Tinutuan. } \\
\text { Sayur tinutuan terdiri dari kombinasi } \\
\text { sayuran kangkung, bayam, jagung dan } \\
\text { beras terdiri zat gizi makro (karbohidrat) } \\
\text { dan mikronutrien (vitamin dan mineral) }\end{array}$ & $\begin{array}{l}\text { - Perubahan rata-rata kadar Hb ibu hamil } \\
\text { sebelum intervensi } 10.34 \mathrm{gr} \% \text { meningkat } \\
\text { menjadi } 11.30 \mathrm{gr} \% \text {, } \\
\text { - Ada pengaruh konsumsi sayur tinutuan } \\
\text { terhadap kadar hemoglobin pada ibu } \\
\text { hamil (p-value }=0,00001 \text { ) }\end{array}$ \\
\hline 2. & $\begin{array}{l}\text { Yulia Fitriani, Ardi } \\
\text { Panggayuh, } \\
\text { Tarsikah }^{8}\end{array}$ & $\begin{array}{l}\text { - Pre eksperimen } \\
\text { - rancangan one } \\
\text { group pre-post test } \\
\text { design. }\end{array}$ & $\begin{array}{l}\text { Jus Jambu } \\
\text { Biji }\end{array}$ & $\begin{array}{l}14 \text { Ibu hamil } \\
\text { trimester III }\end{array}$ & $\begin{array}{l}\text { - Intervensi diberikan jus jambu biji } \\
\text { - Intervensi selama } 7 \text { hari }\end{array}$ & 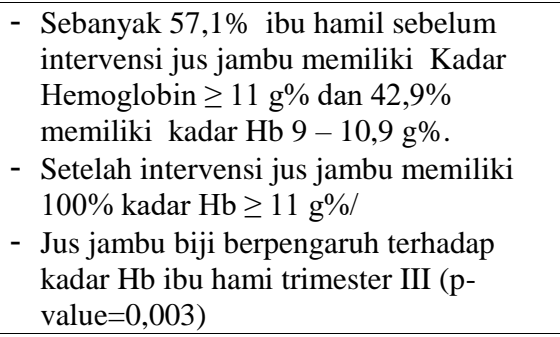 \\
\hline 3 & $\begin{array}{l}\text { Dewi Luh } \\
\text { Retnorini, Sri } \\
\text { Widatiningsih, }^{\text {Masini }^{9}}\end{array}$ & $\begin{array}{l}\text { - Quasi experiment } \\
\text { - pretest-posttest } \\
\text { control group } \\
\text { design. }\end{array}$ & $\begin{array}{l}\text { Sari Kacang } \\
\text { Hijau }\end{array}$ & $\begin{array}{ll}\text { - } & \text { Kelompok } \\
\text { kontrol } 32 \mathrm{ibu} \\
\text { hamil trimester } \\
\text { III } \\
\text { - } \\
\text { Kelompok } \\
\text { intervensi } 32 \mathrm{ibu} \\
\text { hamil trimester } \\
\text { III }\end{array}$ & $\begin{array}{l}\text { - Kelompok Intervensi:tablet Fe dan sari } \\
\text { kacang hijau } \\
\text { - Kelompok Kontrol: tablet Fe }\end{array}$ & $\begin{array}{l}\text { - Ada perbedaan kadar hemoglobin ibu } \\
\text { hamil sebelum dan sesudah diberikan } \\
\text { intervensi tablet Fe dan sari kacang } \\
\text { kedelai. }(9,8906 \mathrm{gr} \% \text { menjadi } \\
\text { 10,7969gr\%) } \\
\text { - Konsumsi tablet Fe dan kacang hijau } \\
\text { dapat meningkatkan kadar hemoglobin } \\
\text { ibu hamil dibandingkan ibu hamil yang } \\
\text { hanya mendapatkan tablet Fe saja. (p- } \\
\text { value }=0,0001 \text { ) }\end{array}$ \\
\hline 4 & $\begin{array}{l}\text { Rifa rahmi, } \\
\text { Zainatun Nazro }^{10}\end{array}$ & $\begin{array}{l}\text { - Quasy Eksperiment } \\
\text { - rancangan one } \\
\text { group pretest- } \\
\text { posttest }\end{array}$ & Rumput Laut & $\begin{array}{l}\text { Ibu hamil } \\
\text { berjumlah } 30 \text { yang } \\
\text { memiliki kadar } \mathrm{Hb} \\
<10 \mathrm{~g} / \mathrm{dl} .\end{array}$ & $\begin{array}{l}\text { - Ibu hamil diberikan rumput laut jenis } \\
\text { Eucheuma Sp } \\
\text { - Intervensiselama } 7 \text { hari. }\end{array}$ & $\begin{array}{l}\text { - Konsumsi rumput laut selama } 7 \text { hari dapat } \\
\text { meningkatkan rata-rata kadar } \mathrm{Hb} \text { sebesar } \\
\text { dari } 8,94 \mathrm{gr} / \mathrm{dl} \text { menjadi } 10,72 \mathrm{gr} / \mathrm{dl}(1,78 \\
\mathrm{g} / \mathrm{dl})\end{array}$ \\
\hline 5 & $\begin{array}{l}\text { Artathi Eka Sundari, } \\
\text { Ossi Happinasari }{ }^{11}\end{array}$ & $\begin{array}{l}\text { - Metode Pretest dan } \\
\text { Posttest control } \\
\text { Group Design }\end{array}$ & Jus buah Bit & $\begin{array}{l}\text { - Kelompok } \\
\text { kontrol } 15 \mathrm{ibu} \\
\text { hamil }\end{array}$ & $\begin{array}{l}\text { Kelompok perlakuan diberikan jus buah } \\
\text { bit sebanyak 500ml dengan tetap } \\
\text { mengonsumsi } \mathrm{Fe} \text {, }\end{array}$ & $\begin{array}{l}\text { - Ada peningkatan rata-rata kadar } \mathrm{Hb} \\
\text { sebelum diberi } \mathrm{Fe}+\mathrm{Bit} 9,70 \mathrm{~g} \% \text { meningkat } \\
\text { menjadi } 10,30 \mathrm{~g} \%\end{array}$ \\
\hline
\end{tabular}




\begin{tabular}{|c|c|c|c|c|c|c|}
\hline No & Penulis & Desain & $\begin{array}{c}\text { Jenis } \\
\text { Suplemen } \\
\text { Makanan }\end{array}$ & Sampel & Metode, Lama Intervensi & Hasil \\
\hline & & & & $\begin{array}{l}\text { - kelompok } \\
\text { perlakuan } 15 \\
\text { orang }\end{array}$ & $\begin{array}{l}\text { - Kelompok kontrol hanya diberikan Fe } \\
\text { saja } \\
\text { - Intervensi selama } 7 \text { hari. }\end{array}$ & $\begin{array}{l}\text { - Setelah pemberian } \mathrm{Fe} \text { dan } \mathrm{Fe}+\text { bit di } \\
\text { wilayah puskesmas Purwokerto Selatan } \\
\text { (p-value }=0,009 \text { ) terdapat perbedaan } \\
\text { peningkatan kadar } \mathrm{Hb} \text {. }\end{array}$ \\
\hline 6 & $\begin{array}{l}\text { KH Endah Widhi } \\
\text { Astuti, Sugit, Anik } \\
\text { Hutari Widyastuti }^{12}\end{array}$ & $\begin{array}{l}\text { - Pre Eksperimental } \\
\text { - Desain Studi One } \\
\text { Group Pretest- } \\
\text { Postest }\end{array}$ & $\begin{array}{l}\text { Jus Bayam } \\
\text { Merah }\end{array}$ & $\begin{array}{l}20 \text { ibu hamil } \\
\text { trimester II }\end{array}$ & $\begin{array}{l}\text { - Ibu hamil diberi jus bayam merah } \\
\text { sehari sekali selama } 2 \text { minggu (14 } \\
\text { hari) } \\
\text { - Intervensi selama } 14 \text { hari } \\
\text { - Pengukuran Hb pada hari ke tujuh dan } \\
\text { hari ke empat belas }\end{array}$ & $\begin{array}{l}\text { - Rata-rata kadar Hb sebelum intervensi } \\
\text { dari } 11,21 \mathrm{~g} \% \text { meningkat } 11,85 \mathrm{~g} \% \text { ( } 7 \text { hari) } \\
\text { dan } 12,14 \mathrm{~g} \% \text { (14 hari) setelah intervensi } \\
\text { - ada perbedaan kadar HB sebelum dan } \\
\text { sesudah konsumsi jus bayam merah (p- } \\
\text { value }=0,004) \text {. }\end{array}$ \\
\hline 7 & $\begin{array}{l}\text { Farida Amalia } \\
\text { Yuliandani,Retno } \\
\text { Kusuma Dewi, } \\
\text { Wilujeng Kartika } \\
\text { Ratri }{ }^{13}\end{array}$ & $\begin{array}{l}\text { - Quasi experiment } \\
\text { - Pretest-Postest } \\
\text { Design with } \\
\text { Kontrol Group. }\end{array}$ & $\begin{array}{c}\text { Ubi Jalar } \\
\text { (Ipomoea } \\
\text { Batatas) }\end{array}$ & $\begin{array}{ll}\text { - } & \text { Kelompok } \\
\text { Kontrol = 22 ibu } \\
\text { hamil trimester } \\
\text { III } \\
\text { - } \\
\text { Kelompok } \\
\text { intervensi = 22 } \\
\text { ibu hamil } \\
\text { trimester III } \\
\end{array}$ & $\begin{array}{l}\text { - Ubi jalar diberikan kepada kelompok } \\
\text { intervensi bersama dengan pemberian } \\
\text { tablet Fe } \\
\text { - Kelompok kontrol hanya diberikan tablet } \\
\text { Fe. }\end{array}$ & $\begin{array}{l}\text { - Kadar Hb ibu hamil sebelum diberikan } \\
\text { intervensi memiliki rata-rata } 10.8545 \\
\text { meningkat menjadi 11,4318 (kenaikan } \\
0,58 \text { ) } \\
\text { - Konsumsi ubi jalar berpengaruh untuk } \\
\text { meningkatkan kadar hemoglobin ibu } \\
\text { hamil (p- value 0,0001). }\end{array}$ \\
\hline 8 & $\begin{array}{l}\text { Akhmad Mahyuni, } \\
\text { Sugeng Riyanto, } \\
\text { Muhhalimah }^{14}\end{array}$ & $\begin{array}{l}\text { - Quasi experimental } \\
\text { - Pre-post test } \\
\text { design }\end{array}$ & $\begin{array}{c}\text { Sayuran } \\
\text { Kalakai } \\
\text { (Stenochlaena } \\
\text { palustris) }\end{array}$ & $\begin{array}{l}\text { - Kelompok } \\
\text { Kontrol = } 12 \mathrm{ibu} \\
\text { hamil anemia } \\
\text { trismester II } \\
\text { - Kelompok } \\
\text { Intervensi = 12 } \\
\text { ibu hamil anemia } \\
\text { trimester 2 }\end{array}$ & $\begin{array}{l}\text { - Kelompok Kontrol = pemberian tablet } \\
\text { Fe } \\
\text { - Kelompok Intervensi = pemberian } \\
\text { konsumsi sayuran kalakai tanpe tablet Fe } \\
\text { - Intervensi } 22 \text { hari }\end{array}$ & $\begin{array}{l}\text { - Perubahan rata-rata kadar hb pada } \\
\text { kelompok pemberian tablet Fe dari } 9,40 \\
\text { menjadi } 10,49 \\
\text { - Perubahan rata-rata kadar Hb pada } \\
\text { kelompok pemberian konsumsi kalakai } \\
\text { dari } 9,32 \text { menjadi } 10,24 \\
\text { - ada peningkatan kadar Hb setelah } \\
\text { diberikan sayuran kalakai (p- } \\
\text { value }=0,0001 \text { ) } \\
\text { - tidak ada perbedaan yang sig rata-rata } \\
\text { kadar Hb antara Ibu yang mengkonsumsi } \\
\text { tablet Fe dengan Ibu yang mengkonsumsi } \\
\text { sayuran kalakai (p-value }=0,262 \text { ) }\end{array}$ \\
\hline 9 & $\begin{array}{l}\text { Nadimin, V. H., } \\
\text { Suryani A., } \\
\text { Agussalim, B }{ }^{15}\end{array}$ & $\begin{array}{l}\text { - Randomized double } \\
\text { blind design } \\
\text { - Pre-post test } \\
\text { controlled }\end{array}$ & $\begin{array}{c}\text { Daun Kelor } \\
\text { (moringa leaf) }\end{array}$ & 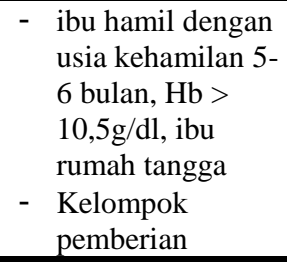 & $\begin{array}{l}\text { - Kelompok ibu hamil dengan pemberian } \\
\text { ekstrak daun kelor } \\
\text { - Kelompok ibu dengan pemberian tablet } \\
\text { besi (60mg Fe, } 0.25 \mathrm{mg} \text { folic) } \\
\text { - Intervensi selama } 12 \text { minggu }\end{array}$ & $\begin{array}{l}\text { - Kelompok intervensi daun kelor: } 11,283 \\
\text { g/dL meningkat menjadai } 11,754 \mathrm{~g} / \mathrm{dL} \\
\text { (p value } 0,040) \\
\text { - kelompok tablet Fe: meningkat ( } \mathrm{p} \text {-value }= \\
\text { 0,002) dari sebelum dan sesudah } \\
\text { intervensi } \\
\text { - tidak terdapat perbedaan peningkatan }\end{array}$ \\
\hline
\end{tabular}




\begin{tabular}{|c|c|c|c|c|c|c|}
\hline No & Penulis & Desain & $\begin{array}{c}\text { Jenis } \\
\text { Suplemen } \\
\text { Makanan }\end{array}$ & Sampel & Metode, Lama Intervensi & Hasil \\
\hline & & & & $\begin{array}{l}\text { ekstrak daun } \\
\text { kelor }=35 \text { orang } \\
\text { - } \quad \text { Kelompok } \\
\text { pemberian tablet } \\
\mathrm{Fe}=35 \text { orang }\end{array}$ & & $\begin{array}{l}\text { kadar Hb pada } 2 \text { kelomopok intervensi } \\
\text { (p-value }=0,168)\end{array}$ \\
\hline 10 & Sugita, Supiati ${ }^{16}$ & $\begin{array}{l}\text { - Quasiexperimen } \\
\text { - Non-randomized } \\
\text { control group } \\
\text { pretest-postest } \\
\text { design. }\end{array}$ & $\begin{array}{l}\text { Telur Ayam } \\
\text { ras Rebus }\end{array}$ & $\begin{array}{c}30 \text { ibu hamil } \\
\text { trimester } 2 \text { dibagi } 2 \\
\text { kelompok }\end{array}$ & $\begin{array}{l}\text { - Kelompok Intervensi: tablet Fe + telur } \\
\text { ayam ras rebus } 1 \text { hari } 1 \text { kali } \\
\text { - Kelompok Kontrol: tablet Fe } \\
\text { - Intervensi } 30 \text { hari }\end{array}$ & $\begin{array}{l}\text { - Kelompok intervensi terjadi perubahan } \\
\text { rata-rata kadar Hb dari } \\
12,013 \pm 1,0322 \mathrm{gr} / \mathrm{dl} \text { meningkat menjadi } \\
13,740 \pm 1,0176 \\
\text { - Ada perbedaan kadar Hb ibu hamil } \\
\text { trimester II sebelum dan sesudah } \\
\text { konsumsi tablet Fe antara kelompok } \\
\text { dengan konsumsi telur ayam ras rebus } \\
\text { dan kelompok tanpa konsumsi telur ayam } \\
\text { ras rebus (p value } 0,001 \text { ) }\end{array}$ \\
\hline 11 & $\begin{array}{l}\text { Dheny Rohmatika, } \\
\text { Supriyana, } \\
\text { Djamaluddin } \\
\text { Ramlan }^{17}\end{array}$ & $\begin{array}{l}\text { - Quasy experimental } \\
\text { - Randomized } \\
\text { pretest-posttest with } \\
\text { control grup design }\end{array}$ & $\begin{array}{c}\text { Ekstrak } \\
\text { Bayam Hijau }\end{array}$ & 34 ibu hamil & $\begin{array}{l}\text { - Kelompok I diberikan ekstrak bayam } \\
\text { hijau } \\
\text { - Kelompok II diberikan tablet Fe } \\
\text { - Intervensi dilakukan selama } 7 \text { hari }\end{array}$ & $\begin{array}{l}\text { - Terjadi perubahan kadar rata-rata } \\
\text { hemoglobin pada kelompok ekstrak } \\
\text { bayam hijau sebesar 0,541 gr/dl. } \\
\text { - Terjadi perubahan kadar rata-rata } \\
\text { hemoglobin pada kelompok tablet Fe } \\
\text { sebesar } 0,22 \text { gr/dl } \\
\text { - Terdapat perubahan kadar hemoglobin } \\
\text { (p.value } 0,038 \text { ) karena pengaruh } \\
\text { konsumsi ekstrak bayam hijau }\end{array}$ \\
\hline
\end{tabular}




\section{PEMBAHASAN}

Berdasarkan analisis jurnal yang telah dilakukan didapatkan bahwa dalam meningkatkan Hemoglobin dalam darah tidak hanya diatasi dengan pemberian suplemen Fe tetapi juga diperlukan pemberian suplemen makanan pada ibu hamil. Suplemen makanan yang telah dikaji dalam literatur jurnal tersebut berupa makanan yang mengandung zat-zat yang dapat meningkatkan penyerapan absorbsi $\mathrm{Fe}$ (enhancer $\mathrm{Fe}$ ).

Analisis asupan Fe dilakukan dengan dua metode yaitu dengan metode kuantitatif dan kualitatif. Metode kuantitatif untuk mengetahui asupan Fe seseorang dengan metode recall yaitu mencatat konsumsi makanan terkait jenis dan jumlah bahan makanan yang dikonsumsi pada periode 24 jam yang lalu yang kemudian secara kuantitatif data akan dihitung nilai gizinya per hari. Menurut E Siong, disarankan menggunakan recall 24 jam konsumsi gizi untuk survei konsumsi gizi individu dikarenakan dari sisi praktis dan keabsahan data dapat diperoleh dengan baik selama yang melakukan terlatih. ${ }^{18}$ Adapun metode kualitatif, konsumsi pangan dilakukan dalam bentuk frekuensi penggunaan bahan makanan yang mengandung Fe dengan pemberian skor, yaitu : Sering sekali (>1x/hari) skor 50, Sering dikonsumsi (1x/hari)skor 25, Biasa dikonsumsi (3x/minggu)skor 15, Kadangkadang dikonsumsi (1-2x/minggu)skor 10, Jarang dikonsumsi ( $<1 \mathrm{x} /$ minggu) skor 1 , Tidak pernah dikonsumsi skor $0 .{ }^{19}$

Peraturan Menteri Kesehatan No. 88 Tahun 2014 menjelaskan bahwa program pemberian tablet tambah darah yang diberikan kepada wanita usia subur dan ibu hamil. Bagi wanita usia subur diberikan sebanyak 1 (satu) kali seminggu dan 1 (satu) kali sehari selama haid dan bagi ibu hamil setiap hari atau minimal 90 (sembilan puluh) tablet, dimana tiap tablet mengandung zat besi setara dengan $60 \mathrm{mg}$ besi elemental (dalam bentuk sediaan Ferro
Sulfat, Ferro Fumarat atau Ferro Gluconat) dan Asam Folat 0,400 mg. ${ }^{20}$ Berdasarkan literatur review pada kelima jurnal pada tabel diatas 4 diantaranya didapatkan bahwa asupan jenis makanan dan pemberian suplemen zat besi pada ibu hamil berpengaruh terhadap kadar Hemoglobin. Hal ini sesuai dengan penelitian yang dilakukan oleh Ulwiyatun dkk dalam penelitiannya didapatkan bahwa kelompok perlakuan yang diberikan rumput laut dan tablet Fe selama 7 hari mengalami peningkatan ratarata hemoglobin lebih tinggi yaitu dari 9,373 gram/dl menjadi 10,847 gram/dl. Sedangkan kelompok control yang hanya konsumsi suplemen Fe saja mengalami peningkatan yang lebih kecil yaitu dari 9,393 gram/dl dan 10,180 gram $/ \mathrm{dl}^{37}$

Selain Peraturan Kementerian Kesehatan No. 88 Tahun 2014 tentang pemberian Tablet Fe selama 90 hari, Program Indonesia Sehat yang dilakukan oleh Kementerian Kesehatan Republik Indonesia Tahun 2016 juga melakukan berbagai upaya pendekatan program salah satunya adalah penurunan Angka Kematian Ibu (AKI) dan Angka Kematian Bayi (AKB) serta penurunan stunting. Adapun upaya pemerintah yang dilakukan untuk ibu hamil dan ibu bersalin meningkatkan mutu Ante Natal Care (ANC) terpadu, intervensi pada 1000 hari pertama kehidupan anak serta program pemberian makanan tinggi kalori, protein, dan mikronutrien (TKPM). ${ }^{21}$

Kecukupan kebutuhan Fe tidak hanya dipenuhi dari konsumsi makanan sumber $\mathrm{Fe}$ atau pemberian $\mathrm{Fe}$ saja, tetapi perlu diberikan makanan yang mempercepat (enhancer) penyerapan $\mathrm{Fe}$ serta mengurangi konsumsi makanan yang menghambat (Inhibitor) penyerapan Fe. Perubahan fisiologis tubuh ibu hamil, ibu menyusui meningkatkan kebutuhan $\mathrm{Fe}$ bagi tubuh, jenis makanan yang dimakan yang dapat mempengaruhi bioavabilitas $\mathrm{Fe}$ dalam tubuh. ${ }^{22}$ 
Penelitian oleh Retorini menunjukkan bahwa kelompok yang diberi tablet Fe saja tidak cukup meningkatkan kadar Hemoglobin, sebaliknya pada kelompok yang diberikan tambahan sari kacang hijau terdapat peningkatan kadar $\mathrm{Hb}$ ibu hamil. ${ }^{9}$ Hal tersebut terkait faktor -faktor yang meningkatkan kadar $\mathrm{Hb}$ ibu hamil seperti buah yang mengandung vitamin C, Vitamin B , serta makanan mengandung zat gizi dan protein tinggi. ${ }^{23}$ Kandungan zat besi dalam kacang hijau paling banyak terdapat pada embrio dan kulit bijinya, ${ }^{24}$ dengan jumlah kandungan zat besi pada kacang hijau sebanyak 6,7 mg per 100 gram. Mengkonsumsi dua cangkir kacang hijau setiap hari berarti mengkonsumsi 50\% kebutuhan besi setiap hari yaitu $18 \mathrm{mg}$ dan dapat meningkatkan kadar hemoglobin selama 2 minggu. $^{25}$

Asam askorbat (vitamin C), Asam Folat dan Protein merupakan faktor utama yang mendorong penyerapan zat besi nonhem. Vitamin C meningkatkan penyerapan zat besi nonhem sampai empat kali lipat. Bahan-bahan seperti sitrat, malat, laktat, suksinat, dan asam tartat dapat meningkatkan penyerapan zat besi nonhem pada kondisi tertentu. Vitamin C memiliki faktor reduksi yang bermanfaat meningkatkan absorpsi besi dengan mereduksi besi ferri menjadi ferro sehingga absorpsi besi menjadi efisien dan efektif. ${ }^{26}$

Penelitian Hariyadi menyatakan terdapat kenaikan kadar $\mathrm{Hb}$ ibu hamil setelah pemberian Tablet Tambah Darah (TTD) + vitamin C setiap hari selama 30 hari sebesar $1,09 \mathrm{gr} / \mathrm{dl}{ }^{27}$ Selain itu terdapat kenaikan kadar $\mathrm{Hb}$ setelah diberikan Fe dan Fe dengan buah Bit. ${ }^{11}$ Kandungan buah bit menurut Hembing antara lain adalah: asam folat $34 \%$, kalium $14,8 \%$, serat $13,6 \%$, vitamin C $10,2 \%$, magnesium $9,8 \%$, triptofan $1,4 \%$, zat besi $7,4 \%$, tembaga $6,5 \%$, fosfor $6,5 \%{ }^{28}$

Penelitian yang dilakukan oleh Astuti tedapat pengaruh pemberian jus bayam merah sehari sekali selama 2 minggu berturut-turut pada ibu hamil Trimester II terhadap peningkatan kadar Hb. Kandungan dalam 100 gram bayam merah menurut Tabel Komposisi pangan antara lain protein 2,2 gram, lemak 0,8 gram, Karbohidrat 6,8 gram, besi $7 \mathrm{mg}$, vitamin C 62 gram. $^{12}$

Zat besi di dalam tubuh bergabung dengan molekul protein membentuk feririn, merupakan protein kompleks dan besi. Dalam kondisi transport, zat besi bergabung dengan protein membentuk transferin. Mengangkut besi di dalam darah merupakan fungsi transferin, sedangkan dalam sel mukosa usus halus merupakan fungsi ferritin. Kekurangan zat besi berkaitan dengan peningkatan hemopoesis dan cadangan zat besi yang rendah. Transportasi zat besi terhambat, karena kurangnya asupan protein sehingga akan terjadi defisiensi besi. ${ }^{29}$

Pada tabel diatas didapatkan penelitian yang dilakukan oleh Fitriani diperoleh bahwa pemberian jus jambu dapat meningkatkan kadar hemoglobin. jambu biji mengandung asam askorbat 2 kali lipat dari jeruk yaitu sekitar $87 \mathrm{mg} / 100$ gram jambu biji. Selain itu setiap 100 gram jambu biji juga mengandung 49 kalori, 0,9 gram protein, 0,3 gram lemak, 12,2 gram karbohidrat, $14 \mathrm{mg}$ kalsium, $28 \mathrm{mg}$ fosfor, $1,1 \mathrm{mg}$ besi, $25 \mathrm{SI}$ vitamin A, 0,05 mg vitamin B1 dan 86 gram air ${ }^{8}$ Penelitian Rahmi juga menunjukkan bahwa konsumsi rumput laut selama 7 hari dapat dapat meningkatkan kadar Hemoglobin sebesar 1,78 g/dl. ${ }^{10}$ Rumput laut memiliki komposisi gizi antara lain (1) kadar protein, (2) kadar abu (mineral) (unsur $\mathrm{Ca}, \mathrm{P}$, dan $\mathrm{Fe}$ ), (3) Kadar vitamin A dan vitamin C, (4) kadar lemak, dan (5) kadar alginate. ${ }^{30}$ Hal ini menandakan bahwa zat pendorong (enhancer) zat besi berpengaruh pada kenaikan kadar hemoglobin pada ibu hamil.

Selain zat-zat yang dapat membantu penyerapan zat besi, Anemia juga di pengaruhi oleh zat-zat yang dapat menghambat penyerapan $\mathrm{Fe}$ yaitu fitat (katul, kedelai, jagung, coklat, susu dan kacang-kacangan), polifenol (tanin) pada teh, bayam, kopi, kacang kacangan, kalsium (susu, keju), phospat (susu, keju). ${ }^{23}$ Pada penelitian yang di lakukan oleh Fredrika N dkk bahwa Pemberian tablet $\mathrm{Fe} 90$ tablet dengan membatasi konsumsi teh dan kopi, ditambahkan menu tradisional Tinutuan 
pada ibu hamil terdapat penurunan jumlah ibu hamil yang anemia sebelum dan sesudah dilakukan intervensi. $^{7}$

Pada intervensi yang dilakukan oleh Fredrika, ibu hamil selain diberikan tablet $\mathrm{Fe}$ dan Tinutuan dalam intervensinya. Tinutuan merupakan menu traditional yang mengandung zat gizi makro (karbohidrat) dan zat gizi mikro (vitamin dan mineral). Sayur kangkung, bayam, jagung dan beras yang terkandung dalam Tinutuan kaya akan zat besi. Satu cangkir sayuran kangkung memiliki kadar gizi zat besi sebesar $6.5 \mathrm{mg}$. Asupan makanan kaya zat besi diperlukan ibu hamil untuk memenuhi kebutuhan perhari minimal $60 \mathrm{mg}$, selain asam folat. $^{7}$

Selain itu, Ibu hamil dianjurkan untuk membatasi konsumsi teh dan kopi. Teh memiliki kandungan tanin yang menurunkan penyerapan besi non hem dengan membentuk ikatan komplek tidak dapat diserap. ${ }^{31}$ Penelitian Thankachan menyatakan bahwa konsumsi teh 1-2 cangkir sehari menurunkan absorbsi besi, pada wanita dengan anemia ataupun tidak. Konsumsi satu cangkir teh sehari menurunkan absorbsi Fe sebesar 49\% pada penderita anemia defisiensi besi, sedangkan konsumsi dua cangkir teh sehari menurunkan $67 \%$ absorbsi $\mathrm{Fe}$ pada penderita anemia defisiensi $\mathrm{Fe}$ dan $66 \%$ pada kelompok kontrol. $^{32}$

Roughead menyatakan semakin tinggi konsumsi kalsium akan menurunkan penyimpanan zat besi pada sel darah merah baik dari sumber heme maupun non heme. Sumber protein dari keju, susu sapi, dan telur tidak dapat meningkatkan penyerapan zat besi non heme karena memiliki bioavailabilitas yang rendah. $^{33}$ Hasil penelitian Petry et al. menunjukkan asam fitat yang terkandung dalam kacang-kacangan dapat menurunkan absorbsi $\mathrm{Fe}$ dalam bahan makanan yang dikonsumsi. Selain itu, hasil penelitian Petry et al. menyatakan kandungan polipenol pada kacang-kacangan yang tinggi dapat menurunkan absorbsi Fe sebesar 27\%. ${ }^{34}$

Tanin ketika tercampur air panas menghasilkan asam galat, dalam pencernaan melapisi dinding usus, sehingga absorbsi makanan minimal. Asam galat berada di atas permukaan teh dan terlihat jelas pada teh tubruk dan susu. Konsumsi tanin atau kafein yang sering maka kerak akan menumpuk sehingga proses absorpsi zat gizi ataupun Fe terhambat sehingga jika dikonsumsi terlalu banyak dan konsumsi makanan tidak seimbang maka akan mengakibatkan anemia. ${ }^{35}$ Pemberian tablet $\mathrm{Fe}$ perlu di perhatikan waktu dan cara mengonsumsinya, hal tersebut terkait zat yang dapat menghambat penyerapan zat besi, jika waktu konsumsi zat besi bersamaan dengan konsumsi zat yang dapat menghambat zat besi maka penyerapan dalam tubuh tidak efektif dilakukan sehingga jumlah kadar hemoglobin dalam tubuh tetap rendah.

Menurut penelitian Kathryn et. al menyimpulkan bahwa penentuan diet yang tepat untuk mengatasi anemia $\mathrm{Fe}$ adalah dengan kombinasi diet tinggi sumber $\mathrm{Fe}$ dan enhancer $\mathrm{Fe}$, serta rendah inhibitor Fe. ${ }^{36}$ Kementerian Kesehatan Republik Indonesia pada tahun 2016 melakukan pencegahan dan penanggulangan anemia dilakukan dengan memberikan asupan zat besi yang cukup ke dalam tubuh untuk meningkatkan pembentukan hemoglobin. Upaya yang dapat dilakukan adalah meningkatkan asupan makanan sumber zat besi, fortifikasi bahan makanan dengan zat besi (tepung terigu, beras, minyak goreng, mentega, dan beberapa snack) serta suplementasi zat besi untuk meningkatkan kadar hemoglobin secara cepat, dan perlu dilanjutkan untuk meningkatkan simpanan zat besi di dalam tubuh.

\section{KESIMPULAN DAN SARAN}

Hasil literature review yang telah dilakukan pada 11 jurnal artikel tentang pengaruh suplemen makanan terhadap peningkatan kadar zat besi pada ibu hamil didapatkan hasil bahwa pemberian suplemen $\mathrm{Fe}$ dan asupan makanan yang mengandung zat besi seperti tinutuan dan ubi jalar, yang membantu penyerapan (Enhancer) zat besi seperti vitamin $\mathrm{C}$ pada buah bit, bayam merah dan jus jambu, vitamin B12, asam folat pada sari kacang hijau, serta protein dapat meningkatkan kadar hemoglobin darah pada ibu hamil. Pembatasan konsumsi makanan yang mengandung zat yang menghambat penyerapan (inhibitor) $\mathrm{Fe}$ seperti 
teh, kopi, dan susu sehingga mengoptimalkan absorbsi Fe dalam tubuh.

Berdasarkan literature review yang telah dilakukan, ibu hamil disarankan mengkonsumsi makanan yang seimbang yang mengandung zat gizi makro (karbohidrat, protein dan lemak) serta gizi mikro (vitamin dan mineral ) agar dapat mencukupi kebutuhan selama masa kehamilan. Selain itu, ibu hamil disarankan

\section{DAFTAR PUSTAKA}

1. Kementerian Kesehatan RI. InfoDatin: Mother's Day. Jakarta; 2014.

2. WHO. Iron deficiency anaemia: assessment, prevention and control. 2001.

3. Kemenkes. Buku Saku Pemantauan Status Gizi dan Indikator Kinerja Gizi Tahun 2015. 2016;42-84.

4. Lee AI. Anemia in Pregnancy. Hematol Oncol Clin. 2011;25:241-59.

5. Badan Penelitian dan Pengembangan Kesehatan. Riset Kesehatan Dasar (RISKESDAS) 2013. Lap Nas 2013. 2013;1-384.

6. Wiknjosastro S. Ilmu Kebidanan. Jakarta: Yayasan Bina Pustaka Sarwono Prowihardjo; 2005.

7. N.Losu F. Asupan Menu Tradisional Tinutuan terhadap Kadar Hemoglobin Ibu Hamil di Wilayah Kerja Puskesmas Bahu Kota Manado. JIK. 2015;9(2):117-20.

8. Fitriani Y. Pengaruh pemberian jus jambu biji terhadap kadar hb pada ibu hamil trimester iii di polindes krebet kecamatan bululawang kabupaten malang. EDUMidwifery. 2017;1(2):79-86.

9. Retnorini DL, Widatiningsih S. Pengaruh Pemberian Tablet Fe Dan Sari Kacang Hijau. J Kebidanan. 2017;6(12):8-16.

10. Rifa R. Efektifitas Konsumsi Rumput Laut Untuk Meningkatkan Kadar Haemoglobin. J Endur. 2018;3(1):195-9.

11. Suryandari AE. Jurnal Kebidanan Diberi Fe dengan Fe Dan Buah Bit Di Wilayah Kerja Amaranthaceae dan memiliki nama latin zat besi sekitar hampir $7 \%$ serta asam folat. J K. 2015; VII(01):36-47.

12. Astuti KEW. Pengaruh Konsumsi Jus Bayam Merah terhadap Peningkatan Kadar mengkonsumsi makanan mengandung vitamin $\mathrm{C}$, B12, asam folat dan protein untuk meningkatkan absorbsi Fe dalam tubuh serta menghindari mengkonsumsi makanan sumber $\mathrm{Fe}$ bersamaan dengan makanan yang dapat menghambat absorbsi Fe seperti teh, kopi dan susu. Sebaiknya diberi jeda. Sehingga absorbsi Fe tetap berjalan secara optimal.

$\mathrm{Hb}$ pada Ibu Hamil di Kecamatan Tawangmangu. J Ilmu Kebidanan. 2015;6(1):72-9.

13. Yuliandani FA, Dewi RK, Ratri WK. Jurnal Riset Kesehatan Peningkatan Kadar Hemoglobin Ibu Hamil Trimester III. J Ris Kesehat. 2017;6(2):28-34.

14. Mahyuni A. Perbandingan antara Pemberian Tablet Fe dan Mengkonsumsi Sayuran Kalakai (Stenochlaena palustris) pada Ibu Hamil terhadap Kenaikan Kadar $\mathrm{Hb}$ di Puskesmas Gambut. Jurkessia. 2015;6(1):10-6.

15. Nadimin, V. H., Suryani A., Agussalim, B. The Extract of Moringa Leaf Has an Equivalent Effect to Iron Folic Acid in Increasing Hemoglobin Levels of Pregnant Women: A randomized Control Study in the Coastal Area of Makassar. Int J Sci BAsic Appl Res. 2015;22(1):287-94.

16. Sugita. Pengaruh Konsumsi Telur Ayam Ras Rebus Terhadap Peningkatan Kadar Hb Pada Ibu Hamil Trimester Ii Di Bpm Wilayah Kerja Puskesmas Klaten Tengah Sugita, Supiati. J Terpadu Ilmu Kesehat. 2016;5(2):110-237.

17. Dheny Rohmatika, Supriyana, Djamaluddin Ramlan. Efektifitas Pemberian Ekstrak Bayam terhadap Peningkatan Kadar Hemoglobin pada Ibu Hamil dengan Anemia Ringan. J Kebidanan. 2017;IX(02):101-212.

18. Tee E, Dop MC, Winichagoon P. Future challanges. In: Proceeding of the Workshop on Food-Consumption Surveys in Developing Countries. 2004. p. 407-14.

19. Wijayanti L. Survei Konsumsi Gizi. Semarang: UNDIP; 2009.

20. Kemenkes. PMK No. 88 Tablet Tambah Darah. Kemenkes 2014. Jakarta: 
Kepmenkes RI; 2014. p. 1-5.

21. Kemenkes RI. Pedoman Umum: Program Indonesia Sehat dengan Pendekatan Keluarga [Internet]. Kemenkes RI. Jakarta: Kemkes RI; 2016. 1-5 p. Available from: http://www.depkes.go.id/article/view/1707 0700004/program-indonesia-sehat-denganpendekatan-keluarga.html

22. Patimah S. Pola Konsumsi dan Kadar Hemoglobin pada Ibu Hamil di Kabupaten Maros Sulawesi Selatan. Makara Kesehat. 2011;15(1):31-6.

23. Citrakesumasari. Anemia Gizi: Masalah dan Pencegahannya. Yogyakarta: Kalika; 2012.

24. Astawan. Sehat dengan Hidangan Kacang dan Biji-Bijian. Jakarta: Penebar Swadaya; 2009.

25. Heltty. Pengaruh jus kacang hijau terhadap kadar Hemoglobin dan Jumlah Sel Darah dalam Konteks Asuhan Keperawatan Pasien Kanker dengan Kemoterapi di RSUP Fatmawati Jakarta. Universitas Indonesia; 2008.

26. Syatriani S, Aryani A. Konsumsi Makanan dan Kejadian Anemia pada Siswi Salah Satu SMP di Kota Makassar. J Kesehat Masy Nas. 2010;4(No. 6):251-4.

27. Hariyadi D. Efektifitas Vitamin C terhadap Kenaikan Kadar $\mathrm{Hb}$ pada Ibu Hamil di Kecamatan Pontianak Timur. J Vokasi Kesehat. 2015;1(5):146-53.

28. Wijayakusuma H. Ramuan Herbal Penurun Kolesterol. Jakarta: Pustaka Bunda; 2008.

29. Almatseir S. Prinsip Dasar Ilmu Gizi. Jakarta: Gramedia Pustaka Utama; 2009.

30. Handayani T. Analisis Komposisi Nutrisi Rumput Laut Sargassum crassifolium. Biofarmasi. 2004;2(2):45-52.
31. Temme E, Hoydonck P Van. REVIEW Tea consumption and iron status. Eur $\mathrm{J}$ Clin Nutr. 2002;56:379-86.

32. Thankachan P, Walczyk T, Muthayya S, Kurpad A V., Hurrell RF. Iron absorption in young Indian women: The interaction of iron status with the influence of tea and ascorbic acid1-3. Am J Clin Nutr. 2008;87(4):881-6.

33. Roughead ZK, Zito CA, Hunt JR. Inhibitory effects of dietary calcium on the initial uptake and subsequent retention of heme and nonheme iron in humans: Comparisons using an intestinal lavage method. Am J Clin Nutr. 2005;82(3):589_ 97.

34. Petry N, Egli I, Gahutu JB, Tugirimana PL, Boy E, Hurrell R. Stable Iron Isotope Studies in Rwandese Women Indicate That the Common Bean Has Limited Potential as a Vehicle for Iron Biofortification. $\mathbf{J}$ Nutr [Internet]. 2012;142(3):492-7. Available from: http://jn.nutrition.org/cgi/doi/10.3945/jn.11 1.149286

35. Hery W. Antioksidan Alami dan Radikal Bebas. Yogyakarta: Kanisius; 2007.

36. Beck KL, Conlon CA, Kruger R, Coad J. Dietary determinants of and possible solutions to iron deficiency for young women living in industrialized countries: A review. Nutrients. 2014;6(9):3747-76.

37. Ulwiyatun, Runjati, Ari Suwondo. Pengaruh Konsumsi Rumput Laut (Eucheuma Sp) Terhadap Peningkatan Kadar Hemoglobin Dan Status Fe Ibu Hamil Anemia Di Kabupaten Pekalongan. Jurnal Kebidanan 2014 ;Vol.3 No.7. 